J. of Modern African Studies, 54, 1 (2016), pp. 1-35 (C) Cambridge University Press 2016. This is an Open Access article, distributed under the terms of the Creative Commons Attribution licence (http://creativecommons.org/licenses/by/4.o/), which permits unrestricted re-use, distribution, and reproduction in any medium, provided the original work is properly cited. doi:10.1017/Soo22278X1500097X

\title{
Decentralisation in Kenya: the governance of governors*
}

\author{
Nic Cheeseman \\ Department of Politics and International Relations and African Studies \\ Centre, University of Oxford, I3 Bevington Road, Oxford $\mathrm{OX}_{2} 6 \mathrm{LH}$, \\ United Kingdom \\ Email: nicholas.cheeseman@africa.ox.ac.uk \\ GabRiELLE LYNCH \\ Department of Politics and International Studies, University of \\ Warwick, Social Sciences Building, Coventry $C_{4} 7 A L$, \\ United Kingdom \\ Email: g.lynch@warwick.ac.uk \\ and \\ JUSTIN WILLIS \\ Department of History, Durham University, 43 North Bailey, Durham \\ DHI 3 EX, United Kingdom \\ Email: justin.willis@durham.ac.uk
}

A B S T R A C T

Kenya's March 2013 elections ushered in a popular system of devolved government that represented the country's biggest political transformation since independence. Yet within months there were public calls for a referendum to

\footnotetext{
* The authors would like to thank Job Bwonye, Alex Dyzenhaus, Amanda Magisu and Betty Okero for writing the county-level reports that this analysis draws upon. We would also like to thank Dominic Burbidge, who collected county level data in support of this analysis and whose work we draw on in the section entitled 'The design of decentralisation'. Two anonymous reviewers and the editors of $J M A S$ provided comments and suggestions that have significantly improved the quality of the manuscript.
} 
significantly revise the new arrangements. This article analyses the campaign that was led by the newly elected governors in order to understand the ongoing disputes over the introduction of decentralisation in Kenya, and what they tell us about the potential for devolution to check the power of central government and to diffuse political and ethnic tensions. Drawing on Putnam's theory of two-level games, we suggest that Kenya's new governors have proved willing and capable of acting in concert to protect their own positions because the pressure that governors are placed under at the local level to defend county interests has made it politically dangerous for them to be co-opted by the centre. As a result, the Kenyan experience cannot be read as a case of 'recentralisation' by the national government, or as one of the capture of sub-national units by 'local elites' or 'notables'. Rather, decentralisation in Kenya has generated a political system with a more robust set of checks and balances, but at the expense of fostering a new set of local controversies that have the potential to exacerbate corruption and fuel local ethnic tensions in some parts of the country.

\section{N T R O D U C T I O N}

Kenya's March 2013 elections brought into being a system of devolved government that represented the country's biggest political transformation since independence. This reform was undeniably popular: in a 2010 referendum, two-thirds of voters approved a new constitution that included devolution alongside a new Supreme Court and Bill of Rights. The decentralisation measures were extensive, providing for 47 county governments complete with elected governors and assemblies. In the wake of the 2013 elections, early opinion polls found that $85 \%$ of Kenyans approved of the idea of devolution. Yet just a few months later, there were public calls for a referendum to significantly revise the new arrangements, and by July 2014, two separate campaigns to force a public vote on amendments were under way. The first effort was spearheaded by the recently elected county governors, the second by the political opposition. Both were predicated on a belief that the 2010 constitution and associated legislation were not sufficient to prevent the recentralisation of power by the national government. At the same time, multiple disputes emerged within and between the different levels of the new political system.

Focusing on the first of these referendum campaigns - that were led by the county governors - this article seeks to understand the ongoing disputes over the introduction of decentralisation in Kenya, and what they tell us about the potential for devolution to check the power of central government and to diffuse political and ethnic tensions in Africa more widely. We also consider the way in which governors' choice of strategies has been shaped by competition with other elected members at the county level, and the implications that these 
local struggles have for ethnic relations. In both cases, the focus of these disputes has been money, in the form of salaries and development funds. However, this should not be taken to imply that the new kinds of contestation that devolution has inspired can be reduced to a simple scramble for personal enrichment. Rather, it also reflects the awareness of Kenyan political actors that patronage and development funds are central to sustain a political career, and a system of government (Barkan 1976; Barkan and Okumu 1980).

Kenya is a useful test case for the impact of decentralisation in diverse and conflict-prone states for three reasons. First, it has suffered recent experiences of extensive electoral violence in 1992, 1997 and 2007. Second, the political system has historically been over-centralised and dominated by a powerful president. Third, there has been genuine reform: decentralisation was neither killed at birth, as was the case in the nearby Democratic Republic of Congo, nor was it limited to a set of superficial measures with little significance. In addition to the creation of new avenues of local representation in the form of governors and members of county assemblies (MCAs), counties have also been given a voice at the national level through the election of one women's representative to the National Assembly and one senator to represent each county in a newly created second legislative chamber.

When the new constitution was inaugurated in August 2010, most Kenyan commentators, opposition parties and donors focused on the potential benefits of devolution. In line with the most optimistic literature on decentralisation, they extolled both its intrinsic and instrumental virtues. It was hoped that devolution would bring government closer to the people, and provide democratic and development gains, by giving previously marginalised communities an increased stake in the political system and by enabling local solutions to be found for local problems. Most of all, devolution was seen as a means to address Kenya's chronic ethnic conflicts: 'the new Constitution establishes national values and principles of governance that seek to diffuse, if not eliminate altogether, the ethnic tensions fuelled by perceptions of marginalisation and exclusion' (Akech 2010: 20).

But Kenyan devolution was not without its sceptics. County-level political leaders immediately spoke out about their fear that the government would seek to stymie devolution, retain as much power as possible in its own hands, and manipulate county level politicians and bureaucrats to ensure compliance with central priorities. Knowingly or not, these more cautious voices were echoing academic studies that have identified 'recentralisation' as a key obstacle to attempts at decentralisation (Rondinelli 
et al. 1989). Important questions were also raised about the cost of the new system of government, which effectively created 47 new sets of elected representatives and bureaucracies, and the need to avoid the costly duplication of goods and services (World Bank 2011). Academics also warned of two additional threats; namely the devolution of patronage-based politics and corruption; and the potential for devolution to create new winners and losers at the local level, which could exacerbate existing social cleavages and, in the worstcase scenario, create new fault lines of conflict (Boone 2012; Cheeseman et al. 2014).

It is too early to assess the full impact of devolution in Kenya. The new institutional arrangements are still in their infancy: it will take years before they have bedded in, and it would be unfair and hasty to either laud them for their early progress or condemn them for failing to work smoothly thus far. Moreover, this paper does not focus on common criticisms of devolution in Kenya; namely, that it has led to the localisation of corruption (Cornell \& D'Arcy Forthcoming), an inefficient duplication of resources, and the exacerbation of inter-communal conflict (Burbidge 2015b). Instead, this article focuses on the continued political debate and competition over the terms of decentralisation, and argues that the Kenyan experience does not fit into the dominant narrative of recent literature, which tends to emphasise the vulnerability of decentralisation reforms to elite manipulation (see Boone 2003). More specifically, we show that the Kenyan experience cannot be read as a case of 'recentralisation' by national government, nor as one of the capture of sub-national units by 'local elites' or 'notables' (Wunsch 2001). Rather, we argue that Kenya has established a relatively robust form of decentralisation, in which elected county governors have emerged as the agents and focus of new political struggles, capable of acting in concert to protect their own positions.

In making this argument, we draw on field observation, more than $5^{\circ}$ interviews conducted by the three authors spread over two years, ${ }^{1}$ three nationally representative surveys, donor reports and six case studies of county level politics in Bungoma, Embu, Kericho, Kiambu, Kisumu and Nairobi. ${ }^{2}$ These counties were selected to ensure variation in the degree of political competition (one-party dominant to highly competitive), ethnic composition and regional coverage. Based on this evidence, we suggest that Kenya's new governors have emerged as influential and in many cases independent political players for two main reasons. First, the process of constitutional reform-which was precipitated by the 2007 post-election violence and the need for a power-sharing 
government to relegitimate the political system - conferred on governors more political and economic authority than has typically been the case in the developing world (Ndegwa 2002). Indeed, although it is always referred to as a form of 'decentralisation', the constitutional protections afforded to governors and senators, combined with the fact that at least $15 \%$ of government revenue must flow to the county level, mean that in practice the Kenyan system is closer to Nigerian federalism than the sort of limited decentralisation practiced in Malawi and Uganda (Crawford and Hartmann 2008).

Second, the strategies selected by governors have been shaped by the fact that they are required to operate in two very different political arenas at the same time. In order to demonstrate this, we draw on Robert Putnam's theory of two-level games (1988), which he developed to understand international negotiations in which national governments had to consider two audiences: the domestic (trade unions, NGOs, opposition political parties, voters) and the international (other countries and international bodies). He suggested that in this context, national governments faced two very different 'win sets' - one set of outcomes that would be acceptable domestically, and one that would be acceptable internationally. Only outcomes that were acceptable both domestically and internationally were likely to represent a stable equilibrium. On this basis, Putnam argued that we can only fully understand the way in which countries negotiate within this much narrower set of options by using theories that 'account simultaneously for the interaction of domestic and international factors' (Putnam 1988: 430).

We draw on Putnam's intuition to conceptualise the strategies adopted by county governors, who must also operate in two different political arenas - the county level and the national level-at the same time. In the first, governors must try and retain the support of voters and key opinion makers in the face of constant challenges from local competitors, such as MPs and senators who intend to run for the governorship in future. In the second, governors must decide whether to support or oppose the national government's policies, especially with regard to decentralisation. Following Putnam, we suggest that recognising the existence of these two games is crucial because the particularities of each game shape the options available to governors in the other. As we will show, the pressure that governors are placed under at the local level to defend county interests has made it politically dangerous for them to be co-opted by the centre, and so has narrowed their options when negotiating with the national government. 
However, governors do not all face the same pressures. Rather, the impact of this two-level game is refracted through the country's party system. Kenya's governors are drawn roughly equally from parties within the Jubilee Alliance government and the Coalition for Reform and Democracy (CORD) opposition. Being seen to be too close to the national government is far more dangerous for opposition governors given the dispositions of their electorates, especially given the political polarisation and inter-ethnic tensions that have characterised Kenyan politics in recent years (Cheeseman et al. 2014). Of course, opposition leaders also have other reasons to support devolution, because it enables them to gain access to resources that would otherwise be closed to them (Cornell \& D'Arcy Forthcoming). By contrast, Jubilee Alliance-aligned governors are likely to be placed under less pressure to resist central control, and face additional incentives to comply with government demands - such as the promise of safe seats and plentiful finance in future elections. Unsurprisingly, therefore, support for devolution at both the elite and popular level remains highest within opposition strongholds. But as we shall see, despite this qualification, pressure from below has led even those governors who are ardent supporters of the ruling Jubilee Alliance to argue that the funds devolved to the counties should be increased at the expense of the central government, forcing national leaders to go to great lengths to tame their co-partisans. Thus, party politics and ethnic alliances may shape the impact of the twolevel game, but they do not undermine it.

Taken together, the existence of this two-level game and the relative strength of county level governments mean that governors - or at least a significant proportion of them - have both the motivation and the capacity to resist capture by central government. One important implication of this argument is that governors' willingness to challenge the centre has been motivated as much by self-interest and the need to overcome county-level conflicts as it has been about any broader commitment to localism. It is therefore both more reliable, and more sustainable. Another is that decentralisation has generated a polity with a far more robust set of checks and balances, but at the expense of fostering economic inefficiency, corruption and a new set of local controversies that have fuelled ethnic tensions in some parts of the country. The product is a politically significant and popular new tier of government whose overall contribution to democracy, development and national cohesion remains contested and uncertain. 
The academic debate on decentralisation has long pitted enthusiasts against sceptics. Enthusiasts have focused on the theoretical benefits of decentralisation, both intrinsic and instrumental; their intellectual lineage stretching back to de Tocqueville's argument that it was the ability of Americans in the early 18 oos to participate in local government that enabled them to experience political freedom and to stave off the threat of the 'tyranny of the majority' (Tocqueville 1834 [1969]). More modern iterations of this view have emphasised the benefits to democratic decision-making of having a population that feels that they have a stake in the political system. Others have argued that decentralisation offers an escape valve for regional or religious tensions (Suberu 2001); or have stressed the consequent benefits in terms of economic flexibility and service delivery (Bodea \& LeBas 2014). Decentralisation has also been posited as one of the most effective ways to protect democratic gains in Africa and beyond.

Partly inspired by this literature, decentralisation has long been in vogue within the development community. In the 1970s, such support largely stemmed from a desire to sidestep the centralised state and improve service delivery (World Bank 1981). In the late 1980s, emphasis shifted to 'good governance' and the hope that decentralisation would create new avenues through which notoriously corrupt central states might be circumvented and made more democratic (USAID 2009). By the 200os, decentralisation had emerged as something of a cure-all policy prescription.

Sceptics, on the other hand, have tended to focus on the practical barriers to effective decentralisation in particular contexts. One line of critique calls into question the impact of decentralisation on intercommunal relations and levels of national cohesion. Thus, in contrast to the hope that decentralisation will decrease spatial inequalities, research has shown that it often 'accentuates horizontal inequalities between richer and poorer areas as a consequence of differential levels of administrative capacity and ability to raise local resources' (Robinson 2007: 2). Given the kinds of communal tensions that exist in polarised winner-takes-all states such as Kenya (Lynch 2011), such an entrenchment of regional inequalities would likely facilitate political mobilisation along ethnic lines and thus undermine efforts to foster national unity and cohesion. This combination can be toxic. As Brancati has shown (2006), decentralisation often fosters ethnic conflict by encouraging the growth of regional parties that reinforce ethnic identities, 
produce legislation that favours certain groups over others, and fuel ethnic political mobilisation up to and including secession.

A second problem with decentralisation is that its implementation is often manipulated by central political elites to maintain their own power and influence (for a Kenyan example, see Barkan \& Chege 1989). A 'stocktaking study' conducted in 2002 by Stephen Ndegwa found that African states are some of the most centralised in the world and that, even when decentralisation is introduced, central governments often find ways of preventing real power and authority being devolved out of their grasp. As a result, the creation of sub-national governments may be a route not to the decentralisation of power, but rather its deconcentration (Rondinelli et al. 1989). Given this, it should come as no surprise that decentralisation often serves not to reform government, but to localise national-level problems. In this vein, Diane Conyers has posited that 'administrative performance at the local level is, to a large extent, a mirror of that in the country as a whole' (2007: 27). This point is echoed by Gordon Crawford and Christoff Hartmann (2008), whose case studies of Malawi, Uganda and Tanzania demonstrate how devolution of power is far less likely to proceed smoothly where the capacity of central government is weak, political trust is low, and democracy has yet to be consolidated. In this sense, decentralisation is akin to power sharing: it is least likely to work where it is needed most (Cheeseman 2011).

One of the most influential explanations of how such top-down manipulation occurs has been provided by Catherine Boone, who documents how governments can use decentralisation as a strategy to create the appearance of devolving power while in reality defending and entrenching their position. According to Boone, this political sleight of hand is achieved because central elites typically enjoy the capacity to 'co-opt, demobilise, usurp, bypass or modify' local notables (2003: 369). Thus, the periphery can be made to do the work of the centre. Boone's work is an important contribution to the debate, because it emphasises the way in which incumbent governments can instrumentalise processes of decentralisation, and reveals how the type of relationship that emerged between the centre and the periphery can shape the nature of the state.

Taking off from Boone's analysis, we argue that Kenya represents a deviant case in the African context, in which the ability of the central government to recentralise power is comparatively low because the constitution has created both a strong set of county governors and a dynamic set of rival local actors. As a result, governors face considerable incentives to resist central co-option. On the one hand, the intention of 
many senators and MPs to run for governor in the future has encouraged governors to campaign for new powers and sources of revenue with which to secure their re-election. On the other, the likelihood that any evidence of 'selling out' to the national government will be used against them by their county level rivals, has deterred some governors from appearing to be too close to the national government-especially in opposition strongholds. The combination of these two developments has given rise to a complex new political landscape in which there is heated competition at and between all levels of government. Under these conditions, there are significant barriers to the recentralisation of power by central elites.

We begin our discussion of decentralisation in Kenya by explaining why local level actors in Kenya enjoy relatively strong political and economic powers, despite the country's recent experience of ethnic tension and political instability (Cheeseman et al. 2014) before moving on to contests between the governors and other local-level actors, and governors and the centre.

\section{DECENTRALISATION IN KENYA}

To some extent, Kenya fits the pattern of decentralisation in Africa, in which larger and more democratic states are more likely to devolve power. Like Nigeria and South Africa, Kenya is one of the continent's bigger states by landmass, and has a large and varied society. Decentralisation is naturally more likely in such contexts, where the central government sits at a greater distance from its people (Zanker et al. 2015). Like Ghana and Senegal, Kenya is also one of Africa's more open and competitive political systems (although how democratic remains a subject of controversy). The Kenyan political landscape is therefore relatively susceptible to pressure from below, at least when compared with some of the continent's more closed and repressive states. This is reflected in the fact that while the former Kenyan political system was criticised for featuring an 'imperial presidency' (Mutua 2008: 265), the country's ethno-regional politics have always involved some devolution of resources and influence to a local level.

In the independence negotiations of the early 196os, leaders of smaller and more economically marginal ethnic communities (who feared the dominance of a Kikuyu-Luo ethnic elite) successfully pushed for a majimbo or regionalist constitution, which promised to devolve significant powers to eight regional assemblies (Anderson 
2005). However, majimboism was immediately dismantled by the victorious Kenya African National Union (KANU), who had only agreed to it as a means to hasten independence (Lynch 2011: 67). Then in 1983, President Daniel arap Moi granted district administrators new powers to initiate and administer development projects through DFRD. But the early promise of this reform was misleading, and in practice the new political structures were less an attempt to meaningfully decentralise power and more a gambit by Moi to legitimise and strengthen his power through a process of deconcentration (cf. Boone 2003; see Lynch 2011: 118).

With the return to multi-party politics in the early 1990s, the idea of majimboism was revived by the new KANU leadership as a means to mobilise ethno-nationalist sentiments among self-conceived 'locals' against more recent 'migrants' in the cosmopolitan areas of the Rift Valley and at the Coast (Lynch 2011). However, despite the rhetorical resonance of majimboism, divisive ethnic politics - which culminated in pre-electoral ethnic clashes in 1992 and 1997 - did not translate into any actual decentralisation of power. Instead, Kenyans had to wait until the introduction of the Constituency Development Fund (CDF) in 2003 by the new National Rainbow Coalition (NaRC) government for the transfer of greater funds to the sub-national level. Under the CDF, $2.5 \%$ of national revenue is allocated to MPs for the purpose of developing their constituencies. However, it is worth noting that in many ways the CDF was not new, but rather codified a set of existing practices known as harambee (self-help), in which political leaders were expected to help organise and fund local development initiatives. Under President Jomo Kenyatta (1964-1978), harambee formed a central part of the government's development strategy, and local communities were promised that if they constructed public goods such as health clinics and schools the government would cover the running costs. ${ }^{3}$ The CDF thus cemented existing norms regarding the developmental role of local leaders in the public mindset (Cheeseman $2008 \mathrm{~b}$ ). It is as a result of this less well-documented, if uneven, strand in Kenya's history that Ndegwa's rankings put Kenya into the 'high decentralisation' category (2002) even before the reforms of 2010.

However, neither size nor the country's relatively democratic politics can explain why a more substantial system of political devolution was introduced in 2013, when minority communities and some opposition parties had been campaigning for it for over 70 years. The prospect for fundamental political change had looked promising when KANU was finally defeated by NaRC in 2002, but the newly elected President, Mwai Kibaki refused to support a new constitution, despite the fact 
that he had risen to power on the back of a promise to enact a new constitution within 100 days. As a result, his government disintegrated, and his former running mate, Raila Odinga, successfully led a 'no' campaign in a constitutional referendum, by mobilising widespread frustration at the government's watering down of a more radical and participatory document popularly known as the Bomas Draft (Lynch 2006; Mutua 2008). So why was Kibaki prepared to lead the campaign for a 'yes' vote in the referendum of 2010 for a constitution that was at least as radical as the Bomas Draft that he had sidelined five years previously?

As Nelson Kasfir (2015) has argued, elite support for a reform constitution in 2010 can be explained through an unplanned sequence of responses that followed the unprecedented violence of the 2007/8 post-election crisis. The election campaign had been one of the closest in Kenyan history, and ended in acrimony when the validity of Kibaki's narrow victory over Odinga was called into question by both the opposition and European election observers. In the unrest that followed, over 1 , ooo people lost their lives and almost 700,ooo were displaced (Lynch 2009), and there appeared to be a real risk that the country would descend into a period of extended civil conflict (Cheeseman 2008a; Chege 2008).

In the wake of the crisis, the general consensus was that, while the violence was triggered by a disputed election, it was fuelled by deep-rooted problems including a top-heavy political system and a tendency towards winner-takes-all politics (Kenya 2008; Mueller 2008; Branch \& Cheeseman 2009; Lynch 2011), an interpretation that revitalised the longstanding campaign for constitutional reform (Mutua 2008). In this context, the political negotiations that led to an end to the post-election violence and the formation of a coalition government included discussion of the historical causes of the violence, and committed the country's political elite to constitutional reform, which ushered in the 2008 Constitution of Kenya Review Act.

Among other things, this Act established a small Committee of Experts to consolidate prior drafts by resolving inconsistencies between existing draft constitutions. In addition, the public was encouraged to submit their views through memoranda or attendance at public meetings, and a special parliamentary select committee was mandated to consider the draft and offer modifications. High levels of public participation - through the submission of 39,439 memoranda and relatively high turnout rates at the Committee of Expert's public consultative meetings - enhanced the legitimacy of the new draft. Significantly, the proposed constitution drew heavily on the 'Bomas Draft', which 
contained the strongest provisions for decentralisation of the three previous draft constitutions under consideration (Kasfir 2015). As a result, county governors were given real economic and political power enshrined under the Constitution. This was important because the Act empowered parliament to offer amendments to, but not reject, the Committee of Expert's draft. Given that both sides of the political divide had publicly committed to reform, by the time that the new draft reached the legislature, the scope for manoeuvre was also significantly constrained.

Nonetheless, the Committee of Expert's recommendations could still have been undermined. Indeed, the sabotaging of the 2005 draft constitution occurred after it had been sent to parliament. Three other factors appear to have made the new arrangements more palatable to those in power. First, by 2010, Kibaki was in his second and final term as president, and was beginning to think more about his political legacy. Although he was clearly determined to hand power to a sympathetic successor, he followed the pattern of a number of other outgoing African presidents who proved to be more willing to implement reform when their own political fate was no longer on the line (Cheeseman 2010). Second, by 2010, President Kibaki was also in a much weaker position than in 2005. Not only had he been forced to accept a power-sharing government, but his domestic and international legitimacy had fallen following the post-election crisis of 2007/8. Although the Kenyan government remained bullish in its engagement with foreign powers, and continued to benefit from its important role as an American ally in the war-on-terror, Kibaki recognised the need to relegitimise his government. Third, MPs introduced changes to the draft constitution so that it promised to create 47 countries with boundaries modelled on colonial districts, rather than devolving power to the existing eight provinces, as many long-standing proponents of devolution desired (Willis \& Chome 2014: 121). The proposed political units were sufficiently small that it seemed unlikely that any individual county would be able to mount a serious challenge to the central government. As a result, Kibaki's advisors may have underestimated how difficult it would be to re-establish central control once the new system had been established.

The combined effect of the strong historical demand for decentralisation, the actions of the Committee of Experts, and the government's need for political legitimacy, resulted in the adoption of a constitutional draft that conferred real economic and political power on county governments. In turn, the willingness of Kibaki and Odinga to campaign together in favour of the new constitution, recalling the 2002 election 
campaign when the two men worked side-by-side to remove KANU from power, was a remarkable moment of national rapprochement and ensured that the draft passed the referendum with the 'yes' camp securing $68.5 \%$ of the vote.

THE DESIGN OF DEVOLUTION

The constitution that emerged from the 2010 referendum established a number of new political positions at the county level, which draw heavily on the US model of state government. Each county directly elects a Governor, who is given a free hand to appoint the County Executive Council, and is mandated to take the lead when it comes to budget and development planning. However, the Governor's legislative agenda must be approved by the County Assembly, which is comprised of members (MCAs) who are directly elected at the ward level. Counties also directly elect senators, who are intended to play a national-level role, representing their county in the Senate. This newly created second chamber of parliament is designed to defend county interests and help craft bills affecting the counties, but also enjoys wider power such as the ability to impeach the President, Deputy President, Governor and Deputy Governors.

According to the constitution, no less than $15 \%$ of government revenue - KSh 266 bn in 2015 -must be devolved to the county level. It is important to note that this only refers to the funds explicitly transferred to county governments - the national government continues to fund county-level services that have remained in its jurisdiction, such as national security and the police force. In this sense, the total government spend at the county level is considerably higher than the $15 \%$ that must run directly through the county governments. In addition to these revenues, the constitution mandates the national government to establish and manage an Equalisation Fund to strengthen the provision of essential services in historically marginalised communities. However, this Fund only receives $0.5 \%$ of national revenue and has received little attention thus far. Another avenue of fiscal transfer has also been overlooked, namely the ability of the national government to make conditional grants to counties, which is perhaps more surprising given the vague constitutional guidelines on how such grants should be awarded, which has created a system that appears vulnerable to manipulation. Although no conditional grants were allocated in 2013-14, the amount allocated through this mechanism increased from KSh $6 \mathrm{bn}$ to KSh 12 bn between 2014 and 2015 (Table I). 
TABLE I.

Revenue distribution under devolution (KSh) ${ }^{4}$

\begin{tabular}{|c|c|c|c|c|c|}
\hline & $\begin{array}{l}\text { County } \\
\text { allocation }\end{array}$ & $\begin{array}{l}\text { Conditional } \\
\text { grants }\end{array}$ & $\begin{array}{l}\text { County } \\
\text { allocation plus } \\
\text { conditional } \\
\text { grants }\end{array}$ & $\begin{array}{l}\text { Allocation as a } \\
\text { share of } 2009-10 \\
\text { government } \\
\text { revenue } *\end{array}$ & $\begin{array}{l}\text { Allocation as a } \\
\text { share of that } \\
\text { year's national } \\
\text { revenue }\end{array}$ \\
\hline $2013^{-14}$ & $190 \mathrm{bn}$ & & - & $37 \%$ & $21 \%$ \\
\hline $2014^{-15}$ & $227 \mathrm{bn}$ & $6 \mathrm{bn}$ & 233 bn & $43 \%$ & $23 \%$ \\
\hline $2015^{-16}$ & 254 bn & 12 bn & 266 bn & $49 \%$ & $22 \%$ \\
\hline
\end{tabular}

*Last year of fully audited and approved accounts.

Despite the decision to write a minimum threshold for the proportion of funds to be devolved to the county level into the constitution, the last three years have witnessed almost continuous debate concerning the basis on which the proportion of revenues owed to the counties should be calculated, and how much they require to be self-sufficient. An early bone of contention was whether counties should pay for the costs of their staff out of their own budget, or whether this bill should be picked up by the national government. Subsequent disagreement has focused on how much more than the minimum threshold of funds should be devolved given the heavy responsibilities that the counties have been given in terms of priority areas such as healthcare. These battles over revenue allocation are covered in detail in the next two sections, but it is worth noting that discussion of this topic has been complicated by confusion over how the proportion of revenue that the counties receive should be calculated.

The 2010 constitution stipulates that the $15 \%$ of national revenues must be devolved based on the last audited accounts that have been approved by the National Assembly. Due to the sluggish nature of the auditing and approval process, the last set of relevant accounts dates back to 2009-2010. Because the Kenyan economy has grown at around $6 \%$ a year since then - while the baseline for the constitutional threshold has remained the same - the national government has been able to make relatively modest increases in the county allocation while using the 2009-2010 figure to claim that the proportion of revenue allocated to the counties increased from $27 \%$ to $49 \%$ between 2013 and 2015 (Daily Nation 13 March 2014). By contrast, county governors, who are keen to make the case that they require more resources, are fond of quoting the proportion of revenue they receive based on total government revenue in that year. By invoking the spirit rather than 
TABLE I I.

CRA Formula for Revenue Allocation ${ }^{6}$

\begin{tabular}{lc}
\hline \hline Criteria & Weighting \\
\hline Population & $45 \%$ \\
Poverty index & $20 \%$ \\
Land area & $8 \%$ \\
Basic equal share & $25 \%$ \\
Fiscal responsibility & $2 \%$ \\
\hline \hline
\end{tabular}

the letter of the constitution - which imagined that the auditing and approval of accounts would be done on an annual basis - they are able to argue that the proportion of funds they receive has in fact remained constant (Table I). The confusion caused by two sets of leaders quoting different sets of figures has been magnified by the media, which typically fails to specify the basis on which the numbers that it carries were calculated.

Devolved revenues are distributed between the 47 counties on the basis of a formula designed by the Commission on Revenue Allocation (CRA), a body set up by the constitution for this purpose (Table II). 5 According to the formula, all counties receive an equal share of $25 \%$ of national revenues and a further $2 \%$ based on their fiscal responsibilities. The remaining revenues are distributed on the basis of population, poverty and land area. This has led to significant variation in the amount of funds received by different counties, with counties with large populations, such as Nairobi, and high poverty and large land area, such as Turkana, receiving a considerably larger slice of the pie. In February 2015, for example, the County Allocation of Revenue Bill prepared by the National Treasury allotted KSh $12 \cdot 7$ billion to Nairobi, while Lamu received just KSh 2 billion.

Counties are also able to raise their own revenue in certain areas prescribed by the constitution. These include taxes on property, entertainment and any other taxes authorised by an Act of Parliament. In addition, Governors may levy fees and charges in return for directly provided services such as waste management. As with the distribution of national revenues, local revenue generation has been the subject of considerable controversy. Most notably, representatives of the private sector and the National Treasury have accused the counties of infringing on forms of taxation that were intended to be reserved for the national government, resulting in a damaging system of double-taxation that has significantly increased the costs of doing business - especially for those 
firms that work across county borders (Daily Nation, 27 January 2014). To date, however, most counties have struggled to raise significant revenues: the exceptions are the country's economic hubs and tourist destinations: Machakos, Mombasa, Nairobi, Narok and Nakuru (Burbidge 2015b).

The following two sections of the paper examine these early struggles over the distribution of power and resources, focusing on the new sites of competition that have emerged between different elected officials at the county level, and the launch of the governor's campaign for a constitutional referendum to protect and strengthen devolution in 2014. We suggest that the referendum campaign should not be read solely as a response to the efforts of the newly elected Jubilee Alliance government to recentralise power. Rather, we argue that it must also be understood as a central element in a strategy through which governors have, collectively, cast themselves as the embodiment of devolution - the guardians of the very idea of decentralised power - and thus helped position themselves against both the centre and their local competitors.

THE LOCAL ARENA: COUNTY LEVEL COMPETITION

In the discussions around the 2010 constitution, governors were imagined as technocrats. They were to be the chief executives of county governments, preferably people who had not been previously involved in politics. Their role replicated the notional separation of legislative and executive power that runs through the 2010 constitution: along with their cabinet of executive secretaries - all appointed, like the national cabinet - they were quite separate from the county assembly with its elected members (MCAs), whose task was to pass legislation and exercise oversight.

The reality worked out a little differently, in large part because of the considerable economic and political authority vested in the new positions. As a result, technocrats often found themselves outmanoeuvred by politicians and in some cases senior civil servants with strong political connections. One consequence of this development was that while election campaigns featured promises of efficiency and service delivery, they were fought in familiar ways: a mixture of promises of patronage and promotion of communal interests; the distribution of largesse; the use of multiple petty intermediaries to channel gifts and win the trust of local communities; and denigration of opponents (Cornell \& D'Arcy 2014; Willis \& Chome 2014; Chome 2015). Competition was heated not just between parties but also within them, as candidates struggled 
to persuade local opinion makers and party officials to back first their nomination and second their election. Thus, most governors came to power indebted, in some cases financially to those who had sponsored them, but in all cases politically, to those who had campaigned for them and used their influence (whether small or large) to secure votes.

Overall, the March 2013 elections were dominated by a bitter battle for the presidency, fought out by two rival coalitions of parties: Uhuru Kenyatta's Jubilee Alliance and Raila Odinga's CORD. The coalitions, like most of the parties, were newly created and organisationally weak in themselves, but they drew on networks of local mobilisers, which were often at least partly ethnic and which were relatively efficient in turning out voters. However, the organisational weakness of the parties meant that party loyalty among political leaders was weak, and that local patterns of alliance and rivalry did not always follow ethnic lines. In the presidential election, and the national assembly elections, Jubilee emerged victorious, but CORD won more gubernatorial seats (20 as compared with 18) and took the strategically and symbolically significant seat of Nairobi.7

A second aspect of county-level politics that was not foreseen during the constitutional negotiations was just how heated the political battles between county officials would become once they had been elected. Even governors that won their seats convincingly have not enjoyed an easy ride. Instead, different sets of county-level actors have teamed up against each other, with senators seeking to eat into the resources earmarked for governors, MPs struggling to retain their profile, and MCAs attempting to enhance their own positions by using their role as legislative veto players to leverage demands for greater influence. At the same time, a number of senators and MPs have announced that they will vie for governorships in 2017 , while many MCAs have set their sights on entering the National Assembly. In practice, these political aspirations often involve criticism of, and efforts to undermine and frustrate the current governor through, among other things, public criticism of their efforts and mutually profitable alliances with local (or other) MCAs.

It is partly in response to these local challenges that governors have sought to strengthen their own positions as the champions of devolution. Wary of being accused of failing to represent local interests and in need of further resources to withstand the challenge from their rivals, the vast majority of governors have campaigned for greater funds while resisting government co-optation. In this way, pressures from within the local arena have led governors to adopt a more 
combative stance within the national arena. As we shall see, many governors have responded to the two level game that they now find themselves playing by occupying a "sweet spot" on the spectrum between pro-centralisation and pro-decentralisation in which they are sufficiently aggressive in their defence of devolution to be seen as defenders of local interests, while being sufficiently careful in how they push their concerns not to make unnecessary enemies at the national level.

One of the most significant sources of difficulty for governors has been the determination of senators to create a role for themselves in county affairs, which itself stems from a discrepancy between the status afforded to senators and the reality of their position under the new political dispensation. Many senior political figures put themselves forward for the position of senator, perhaps thinking that the role would convey the kind of authority and influence that it does in the USA. However, after taking office, many senators came to the rude realisation that in many ways they were the 'spare wheel' of Kenyan decentralisation. An initial battle with the national assembly, which revolved around which legislation had to be passed to the senate for approval, ended in a technical victory for the senate - but the national assembly has continued to sideline the upper chamber (The Star 2 Nov. 2013).

The legislative marginalisation of senators was not the only reason that so many within the second chamber moved into open confrontation with governors. Kenyan voters have historically valued the legislative role of their representatives far less than their ability to link them into sources of patronage and development (Barkan 1976; Barkan \& Okumu 1980). This public association between leadership and development resources now also characterises county level positions, with elected representatives facing considerable pressure from below to protect local interests in terms of both immediate assistance and the promotion and defence of perceived collective interests (Chome 2015). Deprived of any prominent role as the champions of devolution, senators quickly recognised that unless they could position themselves as a source of patronage they risked becoming irrelevant. MPs had retained responsibility for their constituencies (including control over the Constituency Development Fund), and governors had primary responsibility for managing the funds transferred from central to county governments. Even MCAs, the lowest level of elected representative, had successfully lobbied to increase their own emoluments and perks (Standard Digital 16 Nov. 2013), which they justified on the basis of the need for their own 'development funds'. Senators were clearly being left behind in the patronage race. 
Recognising the weakness of their position, a group of senators had already begun to coordinate across party lines by September 2013 . Their aim was to create a role for themselves in county level development activity by arguing for the creation of County Development Boards to coordinate and review development efforts at the county level (Standard Digital 3o Sept. 2013). Unsurprisingly, when the proposed legislation was introduced to parliament by Nandi Senator Stephen Sang, it transpired that senators were not only to be represented on the boards, but were specified as their chairs. This measure became the focus for an alliance of convenience between senators and MPs - otherwise usually bitterly opposed to one another-against governors (Daily Nation 24 Feb. 2014).

Although the proposed boards do not have direct control over development funds themselves, the legislation gave them the power to consider and adopt the County Development Plan and the County Budget. It is not yet clear whether this means that the boards will actually have the power to veto development plans and budgets that they deem not to be in the counties' interests, but it seems clear that they will be able to complicate and prolong the process, which may well enable them to secure some concessions. This is significant, because it empowers senators to force home their criticisms of the spending priorities of many governors. In particular, senators have exploited media coverage of some of the more questionable budget lines of county governments to depict their competitors as corrupt and irresponsible. In January 2014, a report by the OCB found that in the first quarter of the 2013-2014 financial year, 55\% of expenditure at the county level went 'towards personal emoluments, $38 \%$ for operations and maintenance, and only $7 \%$ towards development programmes' (Sabahi Online 16 Jan. 2014). At the same time, it was estimated that the counties spent ' 1 billion shillings ( $\$ 12.4$ million) on domestic and foreign travel, $241 \cdot 9$ million shillings $(\$ 2 \cdot 8$ million) on conferences, and 161 million shillings $(\$ 1 \cdot 9$ million) on training'.

Indeed, the frequency and size of county delegations to other African and European states on 'fact finding' missions quickly became a source of considerable scandal and amusement, which culminated in eight countries (including the USA and Rwanda) taking the unusual step of requesting the Kenyan government to block any further delegations on the basis that they are 'not of any value to our bilateral relationship' (The Star 1 Aug. 2014). Echoing comments by the Controller of Budget (Kenya 2014b), Agnes Odhiambo, many senators publicly argued that the budget figures were proof that public funds were being misused. 
Most notably, Senate Majority Leader Kithure Kindiki, criticised the high level of spending on salaries and trips, and pledged to 'push for amendments to the Public Finance Management Act that will ensure that the bulk of the allocations to counties are used for development projects' (Sabahi Online 16 Jan. 2014).

Concerned that senators would be able to use the County Development Boards to block politically expedient expenditure - and to build a platform to challenge for the governorship in future elections-governors moved against what many saw as a blatant attempt to infringe on their authority. The high-profile Governor of Bomet, Isaac Rutto claimed that the Boards were designed to weaken governors and impede development at the county level. However, governors lacked a legislative presence through which to contest the legislation, because members of both the lower house (populated by MPs) and the upper house (populated by senators) had a vested interest in clipping the wings of increasingly assertive governors who threatened their influence in their own bailiwicks. Having failed to defeat the legislation, which was passed by the National Assembly and signed into law by President Kenyatta on 30 July 2014 (Daily Nation 31 July 2014), the Governors' Council of Kenya moved to challenge it in court. ${ }^{8}$ In this way, governors operating in their own selfinterest mobilised to protect county level processes from national level interference.

This broader tension between senators and governors acting en masse has been mirrored by tense individual relationships between elected representatives in many counties. Of course, governor/senator relations vary considerably across the country. They are typically worse in countries where the governor and senator represent different parties and different ethnic groups, and have a history of personal rivalry. In Nairobi, for example, Evans Kidero, a Luo, was elected Governor on the ODM ticket, while Mike Sonko, a Kikuyu, was elected Senator for TNA. Party and ethnic splits were reinforced by a clash of personal styles: while Kidero styles himself more as a progressive technocrat, Sonko is a selfprofessed populist.

Despite rumours throughout 2013 that Kidero had fallen out with Odinga and was being courted by Sonko's party, the relationship between the two rivals deteriorated over time. In March 2014, Sonko reportedly wrote to County Hall 'seeking to bring the governor to account over allegations of corruption and wastage of county resources' (Nairobi News 24 Mar. 2014). In response, Kidero took out a paid advert in a local newspaper to accuse Sonko of showmanship, arguing that despite his purported concern over budgetary issues he regularly missed meetings 
scheduled to discuss development plans (The People 4 May 2014). Not to be outdone, Sonko moved to demonstrate his ability to get things done by launching the 'Sonko Rescue Team', a set of three emergency ambulances and one fire engine that promised to give free services to Nairobi residents, who the Senator claims have been left to fend for themselves by the county's 'ineffective' governor.

In a number of places, these kinds of tensions between the governor and senator drew MCAs into a set of complex political conflicts. At the same time, many MCAs proved willing and able to manipulate tension between county level leaders to assert their own interests, even in assemblies where the party of the governor had a clear majority. Both of these trends can be identified in Embu County, where they have undermined the effectiveness of the county government. The tenure of Embu Governor and TNA representative Martin Wambora began inauspiciously, with a legal challenge to his election. Although the courts upheld his victory, opposition to the Wambora escalated after he took office. The governor's critics alleged that he had failed to openly tender a contract to develop a local stadium and that fertiliser seeds that he had distributed to farmers had failed because they had been improperly sourced (Dyzenhaus 2015).

The senator, speaker and elected MCAs had their own source of grievance, complaining that the governor had delegated too much power to an unelected administrator-his county secretary, Margaret Kariuki. Wambora's loyalty to Kariuki and refusal to listen to his own advisors led two of the governor's supposed allies within Kenyatta's The National Alliance (TNA), local MP Cecile Mbarire and the Speaker of the County Assembly, Justus Mate, to initiate impeachment proceedings to remove him from office. Sensing an opportunity to secure greater leverage over the Governor, 22 of Embu's 33 MCAs supported the bid, despite the fact that 11 of the 20 elected MCAs and nine of the 13 appointed MCAs came from his own party. 9 In response, the Governor immediately took the assembly to court, arguing that it had impeached him unfairly (Dyzenhaus 2015). The Embu High Court agreed with Wambora's appeal and issued a court order for the assembly to withdraw their motion.

However, this was not the end of the matter. The senate proceeded to ignore the order and passed the motion, voting to impeach Wambora. The court subsequently declared the ruling to have no force in April 2014, but this did not stop the assembly from impeaching Wambora a second time. In turn, the governor took his appeal to the Kilimani High Court, which issued a decision preventing the deputy governor 
from being sworn in and allowing Wambora to keep his job while a third case continued in court (Dyzenhaus 2015). It was not until September 2014 that the matter was finally resolved, when the Kilimani High Court ruled that the Assembly had acted incorrectly and officially reinstated Wambora (Daily Nation 30 Sept. 2014).

Although this gave the outward appearance that Wambora had vanquished his rivals, changes to the county budget reveal that Embu's MCAs were able to use the governor's political weaknesses to extract valuable concessions. Instead of Wambora's favoured approach of focusing on a small number of flagship projects, Embu's budget for 20142015 allocated each MCA a total of KES 20 million to spend on projects within their ward at their own discretion. In the heat of the impeachment proceedings, MCAs had used their enhanced leverage to position themselves as the fonts of patronage (Dyzenhaus 2015). Like senators, MCAs understood that unless they could fashion an important role for themselves within the development process, their political influence, and hopes for re-election and parliamentary aspirations, would be undermined.

Less intense but otherwise similar processes played out in many other counties. To date, MCAs have attempted to impeach governors in Bungoma, Kericho and Makueni, and have threatened impeachment in numerous others, while the creation of dedicated ward development funds for MCAs is fast becoming the norm. MCAs have also become conscious of their ability to remove the county executives appointed by the governor-with many executives standing accused of abuse of office, gross misconduct and incompetence. Such allegations may often be deserved, but it is clear that MCAs sometimes also use this oversight role over county executives, not to improve governance, but to negotiate for tenders, contracts, and other favours.

As this potted history of the politics of Embu county suggests, the collective pressure that this kind of behaviour places on governors can be immense. Governor Wambora spent much of his first two years in office not planning new development strategies for the county but simply seeking to protect his own position. It was precisely this kind of experience that motivated Wambora, and others like him, to push for greater financial resources and political power in order to be able to head-off his rivals. For governors in highly contested and competitive counties, defending and expanding the power of the counties was not simply a matter of personal preference, but of self-preservation. Thus, whether the attempts of MCAs to secure greater resources are conceptualised as a form of political rivalry or simply as 'extortion', the net 
effect has been the same: county governors have been forced to pursue the further devolution of national resources in order to simply sustain their positions. In this way, political competition within the local arena has shaped the stance that governors have adopted within the national arena.

THE NATIONAL ARENA: GOVERNORS VERSUS THE CENTRE

Pressure from below, combined with a desire to use their own positions to strengthen their own national profile, has led governors to defend their positions in multiple ways, including efforts to increase the proportion of funds devolved to the counties, resist the extension of control through centrally appointed county commissioners, and assert their own status. In pursuing the latter goal, governors have appropriated familiar performances of state power: flying the national flag from their vehicles, insisting on the use of the title 'Excellency', travelling in motorcades with outriders, using specialised number plates for vehicles, and insisting on their precedence in the complex order of protocol involved in addressing public meetings. Such efforts attracted some ridicule in the media, and adverse public comment on the expenses involved (Daily Nation 15 July 2013). But governors' concern with these symbols was not merely a matter of personal status or conceit; it was an assertion of the status of county government itself, a display of the profound difference between the former system of county and municipal councils, and the new devolved units. Significantly, the economic and political authority invested in governors under the constitution, such as their power to appoint officials, raise various taxes, and determine county spending priorities, has allowed them to go some way towards making their dreams a reality. As a result, the system of devolution began to take on a life of its own.

Crucially, each county was itself now a 'government', not merely a 'council', as in the old system. That term is laden with significance in the Kenyan political context, where people never tire of explaining that serikali - the Swahili for government - is siri kali ('a fierce secret', literally), a half-joking etymology, which effectively captures the sense of government as powerful, inaccessible and dangerous. To insist, as governors did, that they should be called 'Excellency' was to assert the novel claims of county governments to local autonomy and power. The attempt by the central government to remove or restrict these privileges-initiated by the Attorney-General, Githu Muigai, almost 
immediately after the elections - was a direct rebuff to these assertions, and a more or less explicit denial that the county governments were serikali in their own right (Standard 4 April 2013). The dispute over these privileges became an early focus for solidarity amongst governors across party lines, and has been the subject of continued tension between governors and national government.

Isaac Rutto, who had been elected chair of the Council of Governors in April 2013, ${ }^{10}$ was most vocal in asserting such collective rights of governors. In August 2013, he gave a cheerfully disingenuous press interview (Daily Nation 26 Aug. 2013) in which he said:

We have not said the government is scheming to kill devolution. What we have been doing was to draw parallels with what happened in 1963 and 1964 over majimbo. There are a lot of similarities which we can learn from ... If we draw these similarities you will find that what the likes of Tom Mboya did to federalism is what the likes of [National Assembly Majority Leader Aden] Duale are doing now.

Others echoed the implicit accusation that at least some senior national government figures sought to 'kill devolution' (Daily Nation 13 Jan. 2014). Symbols and titles aside, one of the main areas in which the central government moved to reassert its predominance was security and administration. The 2010 constitution implied that the system of provincial administration - which had been an institution of centralised authority in Kenya since independence - would be radically reformed, or even entirely replaced. For generations of Kenyans who had grown up with a sense of the absolute centrality of the district commissioner and chief to the machinery of government, this was a major change (Branch \& Cheeseman 2006)-inspiring for some, alarming for others. However, the National Government Coordination Act, passed in the last weeks of the Kibaki government, smuggled a rather different possibility into the new dispensation, by repackaging the provincial administration as 'national government coordination officers'.

Following this Act, each county has a county commissioner, with deputy and assistant county commissioners below them and the chiefs retained at the lowest level: their role is the co-ordination of national government functions. In this way the provincial administration was 'restructured' as required by the new constitution through new appointments to relabelled offices. In this way the structure of bureaucratic administration was once again deconcentrated, rather than decentralised. However, in contrast to the reforms of the 1980 os, commissioners now had to reckon with a set of confident county leaders legitimated 
through the ballot box, and who saw resisting central government cooptation and control as essential to their own chances of retaining power.

In line with their aspirations to be 'governments', almost all counties set about creating their own administrative structures, parallel to and rivalling the national government coordination officers. Governors appointed administrators at the ward and sub-ward levels, and in many cases made a point of calling public meetings to which national government officials would not be invited, or where they would be publicly subordinated to county officials (which, in Kenyan terms, means being made to address the crowd first). Although in some counties, governors and county commissioners have maintained relatively amicable public relations, in others such as Kilifi, and more recently Mombasa, there have been very public arguments, with governors and commissioners accusing one another of interference and/or incompetence.

In this context, county commissioners' continued control over security, which is constitutionally a national government function, was a particular grievance for some governors, especially where (as at the coast) there were long-running tensions between security services and significant sections of the population. Governors complained both that the security forces were not guaranteeing the safety of their people, and that they were abusing their powers; and they demanded some kind of control over security. For some months it was clear that the county commissioners and their staff were struggling in this new environment. In many counties, various deputy and assistant commissioner posts went unfilled for long periods; and the commissioners reportedly lost, at least for a while, the effective control that they had long exercised over the police.

In May 2014, President Kenyatta issued a policy document entitled 'Framework for Strengthening the Delivery of National Government Functions at the County Level', which expressed concern that some people had 'distorted the definition of devolution to mean the transfer of the functions of National Government to the County Governments' (Kenya 2014a: 3); it reaffirmed the role of county commissioners by explicitly casting them as the representatives of the president in the county, and restated their power to coordinate the activities of all central government departments. Strikingly, the document mentioned Presidential Circular No. 1, issued by Jomo Kenyatta in 1965 , which had a similar content, and it also explicitly expressed concern that reforms in recent decades had weakened national government: 
the authority of the administrative officers in the co-ordination of Government business has been eroded doe to various reform initiative [sic] whose effect has progressively removed the administrator from the centre in terms of co-ordinating Government business.

These statements seemed to be a direct criticism both of the 2010 constitution and of other reforms that preceded it. While the Framework insisted that county commissioners should not 'undermine the authority of the governor', this was an implicit rebuff to governors' demands for a greater security role; it was also a reminder to all of the primacy of the administration in security matters.

Alongside these tensions over administration and security, governors and national government have been in a prolonged struggle over resources. These conflicts have revolved both around the ownership of government assets in the counties (particularly buildings and lands) and, more intractably, around budgets. As already noted, although a small number of counties have significant potential for raising revenue through local property taxes, or through charges on tourism, the constitution does not give counties the ability to levy income or corporation taxes, or to impose charges for the use of 'national infrastructure' (such as major ports) or for mineral extraction. The result is that, although some governors can levy new charges to fund new initiatives, county governments rely heavily on transfers of funds from the Treasury.

That process is itself conditional on approval of the budget, and on satisfactory accounting for monies already disbursed, both of which are managed at the national level by the Office of the Controller of the Budget (OCB). Due to the different perspectives of county and national leaders regarding the proportion of funds that should be devolved, there have been repeated stand-offs between governors on the one hand, and Treasury and OCB on the other (Daily Nation 10 Jan. 2014). In both 2013 and 2014, a number of counties presented budgets that were not approved, either because they involved significant deficits or because the OCB did not find the revenue forecasts plausible. By October 2013, the national government was openly threatening to take over county government functions because of alleged failures of financial management.

While the attempt to defend their symbolic privileges brought governors together, it is this issue of finance that has come to be the focus of the tension that pitted the governors, as a group, against the national government. Across party lines, and across the country, all governors seemed able to agree that the counties should receive more money from the national government; and when Rutto first proposed a 
referendum to amend the constitution in July 2013, he had already decided on this as the focus (Daily Nation 30 July 2013). For some months, the governors' referendum remained in part a negotiating tactic - an effective means to leverage additional funds and to rally governors and present them as the collective guardians of devolution, united in struggle with the national government.

The viability of this strategy was threatened when, in July 2014, Odinga announced a new CORD push for a referendum dubbed Okoa Kenya ('Save Kenya'), which initially included a much broader set of demands for constitutional revisions that included larger county government budgets, but also the need to dissolve the Independent Electoral and Boundaries Commission. As Okoa Kenya came to focus more squarely on devolution, governors found themselves in danger of being either subsumed into, or outflanked by, this new initiative. The subsequent impact of Odinga's intervention brings into sharp relief the way in which party politics shapes the strategies. Those who were firmly within the CORD camp found it relatively easy to offer their support to the initiative because their communities were typically sympathetic to Odinga, and the national government had fewer levers through which to apply pressure. By contrast, figures within the Jubilee Alliance-including Rutto, who is a member of Deputy President William Ruto's United Republican Party, and thus part of the government-were naturally more wary of being seen to back a campaign led by the opposition, despite the obvious benefits they would have received had they been successful. Indeed, due to the high level of ethnic polarisation, it would have been almost impossible for governors elected in Jubilee strongholds to join hands with CORD (Lynch in Saturday Nation 27 Sept. 2014). Thus, despite Odinga's repeated invitations for governors to join the CORD campaign, Rutto's group continued to shun partisan politics.

Instead, governors began to pursue their own campaign more actively, by collecting the signatures required as part of the referendum process (The Star 20 Sept. 2014). The decision to badge their referendum campaign Pesa mashinani, 'money to the grass-roots', was a simple assertion of the governors' desire to focus political debate on finance, and to present the key issue as the battle between national government and devolved governments.

The mobilisation of governors in line with a set of issues supported by the opposition represented a clear threat to the ability of the government to control the political agenda, despite the non-partisan stance of many county leaders. In response, the Jubilee Alliance sought to fracture the movement by turning the referendum issue into one of party 
loyalty: support for a referendum of any kind was presented as proCORD, and resistance as pro-Jubilee. In this way, the government effectively rendered it increasingly difficult for Jubilee governors to support the Pesa Mashinani campaign lest they be labelled as 'traitors' to the Alliance, and thus to their communities. This was significant given the negative implications such a reputation was perceived to have for their chances of re-election, especially in Jubilee-aligned ethnic strongholds. That almost all Jubilee-affiliated governors abandoned the referendum campaign at this point demonstrates the impact of party identities on governors' political positioning, and the continued capacity of the government to weaken challenges to its authority by playing divide-andrule politics.

However, this should not be taken as evidence that the government can limit the influence of the governors at will. For one thing, the national government only succeeded in preventing more power and resources from being decentralised, not in recentralising authority under the president. Moreover, some of the strategies through which the Jubilee Alliance undermined support for the referendum campaign actually strengthened the position of governors within the wider political system. Most notably, the government proved willing to compromise over the issue of funding, pledging to further increase the proportion of government revenue that is devolved to the counties. This enabled Deputy President William Ruto to argue that there was 'no need' for a referendum because some of the core demands of the counties could be met without one (Daily Nation 5 Oct. 2014). This arrangement suited the governors well: the referendum had only ever been a strategy to gain leverage in the battle for greater prestige and resources. Thus, although from the outside this episode appears to end with a victory for the central government, in reality the willingness of the government to make concessions has emboldened governors and strengthened their hand. In this way, the capacity and willingness of governors to work together to advance their collective interests has served to further entrench the system of devolution itself.

CONCLUSIONS: POPULAR OPINION AND THE FUTURE OF D E V OL U T O N

The Kenyan experience with decentralisation is important because it demonstrates the significance of local political competition for the way in which local elites engage with the central state. The new political dispensation, and the emergence of a highly competitive local arena that 
features MPs, senators, governors and MCAs, has required governors to play two political games at different levels of the political system at the same time. In particular, the pressure that governors have been placed under at the local level to defend county interests has made it politically dangerous for them to be co-opted by the centre. The strength of this pressure varies depending on party loyalties and ethnic affiliations, but it can be seen across the political spectrum. The robust defence of decentralisation over the last 16 months should therefore be understood as the product of the combination of the demands placed on governors at the local level, and the considerable economic and political authority vested in them by the constitution and associated legislation. Thus far, the majority of governors have positioned themselves around the 'sweet spot' in which they aggressively defend county interests without moving into all-out confrontation with the national government.

One implication of this conclusion is the need to differentiate the local political scene. 'Local notables' are not a cohesive group in any of Kenya's counties. Rather, they are typically divided along lines of personal rivalry (sometimes exacerbated by ethnic tensions) and they are in fierce competition for the resources offered by government positions. Salaries, allowances, bursary funds, control over licences and property, the issuing of contracts, and the hiring of staff, all come with elected office, and county governments have become a field for vigorous contests over these benefits. As Cornell \& D'Arcy have argued (Forthcoming), governors, senators, MCAs and MPs all vie for such resources, and all have an eye on the next elections and the further prospects for reward that elected office (and larger offices) will bring. Such efforts to undermine and weaken political competitors have generated an extremely dynamic political environment, but they are also problematic, as they encourage unnecessary duplication and obstacles, rather than effective planning and collaboration, and provide incentives to acquire wealth through corrupt means. They also, of course, have the potential to encourage a local politics of violence and intimidation.

Indeed, in some cases the kind of county-level struggles described above have been exacerbated by, and have fed into, communal narratives and histories of inter-ethnic conflict. In Mandera County, for example, violence in 2014 was in part linked to contests between the majority Garre and minority Degodia communities, as the latter argued that the Garre were seeking to generate a political monopoly in the county, while Garre presented the Degodia as 'encroachers' hoping to expand into their homeland (The Star 28 Aug. 2014). Similarly, in Marsabit the rivalry between the governor and one of the local MPs followed 
the lines of long-standing tensions between Gabbra and Boran, leading to an outbreak of violence and threats by the Deputy President to dissolve the county government (Daily Nation, 11 Jan. 2014, 18 Jan. 2014).

In Lamu County, tensions between relatively recent settlers from elsewhere in Kenya - mostly Kikuyu - and those who see themselves as indigenes were managed in the election campaign, when the successful candidate for the governor post had a Kikuyu deputy. However, they exploded in 2014, following a terrorist attack on the mainly Kikuyu settlement of Mpeketoni that exposed multiple tensions between elected county officials from different ethnic groups (The Star, 12 July 2014; Anderson \& McKnight 2015). Thus, while decentralisation has enhanced competition between the national and county governments, and thus provided a new check against centralised power, it has also increased competition over resources and positions at the local level in ways that have intensified county-level tensions and may undermine national cohesion in the future (Burbidge 2015a).

Although there is a very public debate on some of these more problematic aspects, devolution appears to remain generally popular among Kenyans. This is important for two reasons. First, it renders the national government less likely to risk undermining the new arrangements. Second, although decentralisation has exacerbated local tensions in some parts of the country, the fact that it allows long-marginalised communities to elect their own leaders has also boosted the legitimacy of the wider political system. Writing just after the 2013 elections, we argued that the fact that so many Kenyans who 'lost' nationally 'won' locally, such as the Odinga supporters in Nairobi, Nyanza and at the Coast, helped to ensure that the process remained peaceful despite a divisive campaign and disputed result (Cheeseman et al. 2014).

A nationally representative survey conducted in conjunction with Ipsos Synovate in August 2014 supports this interpretation. ${ }^{11}$ While an average of $70 \%$ of Kenyans continued to support the principle of devolution, this figure was lower in pro-government areas, such as the former Central Province, and higher in those places that supported CORD in the 2013 election and have historically felt marginalised from power, such as the former Nyanza (79\%) and Western $(76 \%)$ provinces. The capacity of devolution to restrain some of the centrifugal forces at play in Kenyan politics is confirmed by the reasons that respondents gave for supporting devolution. A clear majority (73\%) explained that they support decentralisation because they believe that it brings more resources to the grassroots and ensures their more equitable distribution. 
In-line with our analysis of the impact of party politics on attitudes to devolution, and hence the strength of public pressure applied to governors, pro-CORD areas are also more likely to support the referendum campaigns discussed in this paper. While $85 \%$ of Kikuyu respondents rejected the idea, following the lead of their co-ethnic Uhuru Kenyatta, $72 \%$ of Luo respondents backed the proposal. The three main reasons that respondents gave for why they backed the campaigns are telling: to secure more funds for the counties $(62 \%)$, to prevent the Jubilee Alliance from reneging on past promises (29\%), and to stop the government sabotaging devolution (14\%). Significantly, the central role played by governors in taking the national government to task, and their conscious attempts to present themselves as the embodiment of decentralisation appear to be working, at least as far as public opinion is concerned. On average, $60 \%$ of respondents declared confidence in governors, as compared with senators at $52 \%$, MCAs at $60 \%$ and county commissioners at $50 \%$.

The combination of vigilant governors, constitutional protections and public popularity suggests that devolution in Kenya is here to stay. This is not to suggest that the recentralisation of power is unthinkable. The central government remains by far the strongest actor in the Kenyan political scene, and continues to control counties' purse strings. Moreover, the ability of the Jubilee Alliance to undermine the momentum of the governors' referendum by playing divide-and-rule party politics demonstrates that the centre well understands how to manipulate the periphery. But these caveats notwithstanding, what is striking about the Kenyan political system is not the ability of the national government to interfere in the decentralisation process, which is well covered in the literature on Africa, but the capacity of county-level governments to fight back, which is not.

\section{N O T E S}

1. Cheeseman and Willis have both visited Kenya every few months over the last three years as part of various research projects, including research in Nairobi, Mombasa and the former Western Province, while Lynch has been based in Nairobi since 2013 and has carried out research in Nairobi, Turkana and throughout the former Rift Valley Province.

2. The case studies were conducted by the research assistants thanked in the acknowledgements to a template created by the authors.

3. Harambee proved to be extremely successful, but the formal system broke down when the public supply of clinics and schools began to outstrip the government's capacity to provide teachers and nurses in the mid 1970 s, and the government was forced to try regulate the number of harambee activities.

4. This table originally appeared in Burbidge $(2015 \mathrm{a})$, and this discussion here draws on conversations with Burbidge in addition to the analysis provided in his original paper. 
5. For more information on the CRA, see: http://www.crakenya.org/.

6. For a full description of the formula, see CRA, 'Revenue Allocation Formula', n.d., http:// www.crakenya.org/information/revenue-allocation-formula/.

7. Nine governors were also elected on the tickets of minor parties, often as a result of disputed party nominations.

8. The case was ongoing at the time of writing.

9. The number of elected MCAs is topped up by a number of nominated MCAs who are selected by party leaders in proportion to their elected seats; a measure intended to represent minority groups and women.

10. A statutory body established as part of the decentralisation reforms.

11. The poll was conducted by Ipsos Synovate on the basis of questions designed by the authors. A nationally representative sample of 2,02 1 people were interviewed about a range of political and economic beliefs and attitudes, including devolution. The margin of error on the poll was $\pm 2 \cdot 2 \%$ with a $95 \%$ confidence interval.

\section{R E F E R E N C E S}

Akech, M. 2010. Institutional Reform in the New Constitution of Kenya. Nairobi: International Centre for Transitional Justice.

Anderson, D.M. 2005. "Yours in Struggle for Majimbo'. Nationalism and the Party Politics of Decolonization in Kenya, 1955-64', Journal of Contemporary History 40, 3: 547-64.

Anderson, D.M. \& J. McKnight. 2015. 'Kenya at war: Al-Shabaab and its enemies in Eastern Africa', African Affairs 1 1 4, 454: 1-27.

Barkan, J.D. 1976. 'Comment: further reassessment of "conventional wisdom": political knowledge and voting behavior in rural Kenya', American Political Science Review 7o, 2: $45^{2-5}$.

Barkan, J.D. \& J.J. Okumu. 1980. 'Linkage without parties: Legislators and constituents in Kenya', in K. Lawson, ed., Political Parties and Linkage: a comparative perspective. New Haven, CT: Yale University Press, 289-324.

Barkan, J. \& M. Chege. 1989. 'Decentralising the state: district focus and the politics of reallocation in Kenya', Journal of Modern African Studies 27, 3: 431-53.

Bodea, C. \& A. LeBas. 2014. 'The origins of voluntary compliance: attitudes toward taxation in urban Nigeria', British Journal of Political Science. FirstView. http://dx.doi.org/10.1017/ Sooo7 $12341400026 \mathrm{X}$.

Boone, C. 2003. 'Decentralization as political strategy in West Africa', Comparative Political Studies 36 : $355^{-80 .}$

Boone, C. 201 2. 'Land conflict and distributive politics in Kenya', African Studies Review 55, 1: 75-103.

Brancati, D. 2006. 'Decentralization: fueling the fire or dampening the flames of ethnic conflict and secessionism?', International Organization 6o, $3: 65^{1-85}$.

Branch, D. \& N. Cheeseman. 2006. 'The politics of control in Kenya: understanding the bureaucratic-executive state, 1952-78', Review of African Political Economy 33, 107: 11-31.

Branch, D. \& N. Cheeseman. 2009. 'Democratization, sequencing, and state failure in Africa: lessons from Kenya', African Affairs 108, 430: 1-26.

Burbidge, D. 2015 a. 'Democracy vs. diversity: ethnic representation in a devolved Kenya', Working Paper. http://princeton.academia.edu/DominicBurbidge.

Burbidge, D. 2015 b. 'County financing at the macro and micro level', Seminar Paper presented at the Public Participation and Local Revenue Generation Workshop, World Bank, Nairobi.

Cheeseman, N. 2008a. 'The Kenyan elections of 2007: an introduction', Journal of Eastern African Studies 2, 2: 166-84.

Cheeseman, N. 2008b. 'Kenya since 2002: the more things change the more they stay the same', in L. Whitfield \& R. Mustapha, eds. Africa Since 2002. London: James Currey, 94-113.

Cheeseman, N. 2010. 'African elections as vehicles for change', Journal of Democracy 21, 4: 139-53.

Cheeseman, N. 2011. 'The internal dynamics of power-sharing in Africa', Democratization 18, 2: $33^{6-65}$.

Cheeseman, N., G. Lynch \& J. Willis. 2014. 'Democracy and its discontents: understanding Kenya's 2013 elections', Journal of Eastern African Studies 8, 1: 2-24.

Chege, M. 2008. 'Kenya: back from the brink?', Journal of Democracy 19, 4: 125-39. 
Chome, N. 2015. "Devolution is only for development"? Decentralization and elite vulnerability on the Kenyan coast', Critical African Studies 7, 3: 299-316.

Conyers, D. 2007. 'Decentralisation and service delivery: lessons from sub-Saharan Africa', IDS Bulletin $38,1: 18-32$.

Cornell, A. \& M. D’Arcy. 2014. 'Plus ca change? County-level politics in Kenya after devolution', Journal of Eastern African Studies 8, 1: 173-91.

Cornell, A. \& M. D’Arcy. Forthcoming. 'Everyone's turn to eat? Devolution and corruption in Kenya', African Affairs.

Crawford, G. \& C. Hartmann. (eds). 2008. Decentralisation in Africa: a pathway out of poverty and conflict? Amsterdam: Amsterdam University Press.

Dyzenhaus, A. 2015. 'Land, local government and minority representation: the experience of decentralisation in Kenya', Unpublished MPhil dissertation, University of Oxford.

Kasfir, N. 2015. 'Agency across changing sites: the path to Kenya's 2010 constitution', in T. Förster \& L. Koechlin, The Politics of Governance. Abingdon: Routledge, $5^{2-71 .}$

Kenya, Republic of. 2008. Commission of Inquiry into Post-Election Violence. Nairobi: Government Printer.

Kenya, Republic of. 2014 a. 'Public Service Commission: Framework for Strengthening the Delivery of National Government Functions at the County Level'. Nairobi: Government Printer.

Kenya, Republic of. 2014 b. Office of the Controller of the Budget, County Governments: Annual Budget Implementation Review Report, $\mathrm{FY}_{2013} \mathrm{OI}_{4}$. Nairobi: Government Printer.

Lynch, G. 20o6. 'The fruits of perception: 'ethnic politics' and the case of Kenya's constitutional referendum', African Studies 65, 2: 233-70.

Lynch, G. 2009. 'Durable solution, help or hindrance? the failings and unintended implications of relief and recovery efforts for Kenya's post-election IDPs', Review of African Political Economy 122: $604^{-13}$.

Lynch, G. 201 1. I Say to You: Ethnic Politics and the Kalenjin in Kenya. Chicago, IL: University of Chicago Press.

Mueller, S. 2008. 'The political economy of Kenya's crisis', Journal of Eastern African Studies 2, 2: $185^{-}$ 201.

Mutua, M. 2008. Kenya's Quest for Democracy: taming Leviathan. Kampala: Fountain Publishers.

Ndegwa, S.N. 2002. Decentralization in Africa: a stocktaking survey. Washington, DC: The World Bank.

Putnam, R. 1988. 'Diplomacy and domestic politics: the logic of two-level games', International Organization 42, 3: 427-6o.

Robinson, M. 2007. 'Introduction: decentralising service delivery? Evidence and policy implications', IDS Bulletin 38, 1: 1-6.

Rondinelli, D.A., J.S. McCullough \& R.W. Johnson. 1989. 'Analysing decentralization policies in developing countries: a political-economy framework', Development and Change 20, 1: 57-87.

Suberu, R. 2001. Federalism and Ethnic Conflict in Nigeria. Washington, DC: United States Institute of Peace.

Tocqueville, A.D. 1834 [1969]. Democracy in America, edited by J. P. Mayer, translated by G. Lawrence. New York, NY: Anchor-Doubleday.

USAID. 2009. Democratic Decentralization Programming Handbook. Washington, DC: USAID.

Willis, J. \& N. Chome. 2014. 'Marginalization and political participation on the Kenya coast: the 2013 elections', Journal of Eastern African Studies 8, 1: $115^{-34}$.

World Bank. 1981. 'Accelerated Development in Sub-Saharan Africa' [Berg Report]. Washington, DC: World Bank.

World Bank. 201 1. 'Navigating the storm, delivering the promise with a special focus on Kenya's momentous devolution', Kenya Economic Update 5.

Wunsch, J.S. 2001. 'Decentralization, local governance and 'recentralization' in Africa', Public Administration and Development 21, 4: 277-88.

Zanker, F., C. Simons \& A. Mehler. 2015. 'Power, peace and space in Africa: revisiting territorial power sharing', African Affairs 1 14, 445: 72-91.

\section{NEWS MEDIA}

Daily Nation (online), Letters: 'Tame county governors before they get too drunk with power', 15 July 2013, http://www.nation.co.ke/oped/Letters/Tame-county-governors/-/440806/1914844/-/ omfgsv/-/index.html. 
Daily Nation (online), 'Governors vow to push for vote in dispute with Jubilee', 3o July 2013, http:// www.nation.co.ke/news/politics/Governors-vow-to-push-for-vote-in-dispute-with-Jubilee/-/ 1064 / 1932268/-/13 hojvt/-/index.html.

Daily Nation (online), 'Rutto speaks on referendum push', Daily Nation, 26 Aug. 2013, http://www. nation.co.ke/news/politics/Rutto-speaks-on-referendum-push/-/1064/1969434/-/9a2ajjz/-/ index.html.

Daily Nation (online), 'County governments report "shallow and dishonest”: governors', 10 Jan. 2014, http://mobile.nation.co.ke/counties/-/195048o/2141452/-/format/xhtml/-/sgjo73z/-/index. html.

Daily Nation (online), 'Seek solution to Marsabit conflict, MPs tell Raila', 11 Jan. 2014, http://mobile. nation.co.ke/news/Seek-solution-to-Marsabit-conflict/-/1950946/2142742/-/format/xhtml/-/ i $47 \mathrm{gf}_{4} /$ /-/index.html.

Daily Nation (online), 'Nyachae warns of “insider plot” to destroy devolution', 13 Jan. 2014, http:// mobile.nation.co.ke/news/Nyachae-warns-of-insider-plot-to-destroy-devolution-/-/1950946/ $2145^{130 /-/ f o r m a t / x h t m l /-/ t 4 h r p t z /-/ i n d e x . h t m l . ~}$

Daily Nation (online), 'Politics a key factor in the perennial Marsabit conflict', 18 Jan. 2014, http:// mobile.nation.co.ke/news/Politics-a-key-factor-in-the-perennial-Marsabit-conflict/-/1950946/ $2151040 /-/$ format/xhtml/-/vrotk 1z/-/index.html.

Daily Nation (online), 'County cheifs must think outside the box', 27 Jan. 2014, http://www.nation. co.ke/oped/Opinion/Counties-Devolution-Taxes-Protests/-/440808/2162564/-/view/ printVersion/-/ogxtp6z/-/index.html.

Daily Nation (online), 'MPs, senators hatch plot to tame judges and governors in battle for supremacy', 24 Feb. 2014, http://mobile.nation.co.ke/news/MPs-Senators-Governors-DevolutionCounties/-/1950946/2220396/-/format/xhtml/-/iyvtg4z/-/index.html.

Daily Nation (online), 'Governors ask for more funds', 13 Mar. 2014, http://mobile.nation.co.ke/ counties/Governors-National-Assembly-Funds-Treasury/-/1950480/2243488/-/format/ xhtml/-/elna57/-/index.html.

Daily Nation (online), 'Law puts senators in charge of county cash', 31 July 2014, http://mobile. nation.co.ke/news/Law-puts-senators-in-charge-of-county-cash/-/ 1950946/2404264/-/format/ xhtml/-/a2j9j3z/-/index.html.

Daily Nation (online), 'Embu speaker to face contempt charges over Wambora's impeachment', 3o Sept. 2014, http://mobile.nation.co.ke/news/Embu-Speaker-to-face-contempt-charges-overWambora-impeachment/-/1950946/2470092/-/format/xhtml/-/iuv9pl/-/index.html.

Daily Nation (online), 'No need for referendum, Ruto says', 5 Oct. 2014, http://www.nation.co.ke/ news/No-need-for-referendum-william-Ruto-says/-/1056/2476416/-/view/printVersion/-/ lof 4 wkz/-/index.html.

Lynch, G. 'Devolution has made politics more local and violent than ever before', Saturday Nation, 27 Sept. 2014 .

Nairobi News (online), 'Sonko writes to County Hall over Kidero's conduct', 26 Mar. 2014, http:// nairobinews.co.ke/househelp-2/, viewed 7 Jan. 2015 .

Sabahi Online (Washington DC), $16 \mathrm{Jan} .2014$, 'Criticism builds over spending practices in Kenyan counties', by Rajab Ramah, http://sabahionline.com/en_GB/articles/hoa/articles/features/ 2014/01/16/feature-o ?format=mobile.

Standard Digital, 'Keynan fights to allow governors to fly national flag', 4 April 2013, http://www.standardmedia.co.ke/article/2000080792/keynan-fights-to-allow-governors-to-fly-national-flag.

Standard Digital, 'Governors take on senators over County Governments Bill, 2013', 3o Sept. 2013, http://www.standardmedia.co.ke/article/ 2000094555/governors-take-on-senators-over-countygovernments-bill-2013.

Standard Digital, 'MCAs win big allowances in salary deal', 16 Nov. 2013 http://www.standardmedia. co.ke/thecounties/article/200oo97796/mcas-win-big-allowances-in-salary-deal.

The People (online), 'Governors under siege as impeachment fever rises', 4 May 2014, http://www. ipsos.co.ke/NEWBASE_EXPORTS/Tullow\% 2oKenya\% 20BV/140504_The\% 20 People\% 2oSunday_21,24_6f84e.pdf.

The Star (online), 'Senate big winner in row with MPs', 2 Nov. 2013, http://www.the-star.co.ke/news/ article-142028/senate-big-winner-row-mps.

The Star (online), 'Lamu leaders differ over violence', 12 July 2014 , http://www.the-star.co.ke/news/ article-176261 /lamu-leaders-differ-over-violence.

The Star, 'Rhamu seat sparks violence in Mandera', 28 Aug. 2014, p. 10. 
The Star (online), 'Governors launch signature collection', 20 Sept. 2014, http://www.the-star.co.ke/ news/article-191429/governors-launch-signature-collection.

The Star (online), ' 8 countries ban Kenyan MCAs from visiting', by Gideon Keter, 1 Aug. 2014, http://www.the-star.co.ke/news/article-1 81695/8-countries-ban-kenyan-mcas-visiting. 